\title{
Two cases of tits' fights to the death in competition for winter roosting sites
}

\author{
Jakub TYPIAK $^{1}$ and Marlena TYPIAK ${ }^{2}$ \\ ${ }^{1}$ Ornithological Station, Museum and Institute of Zoology, Polish Academy of Sciences, Nadwiślańska 108, \\ 80-680 Gdańsk, Poland, e-mail: jakub.typiak@wp.pl (corresponding author) \\ ${ }^{2}$ Fryderyka Chopina 3/3, 80-268 Gdansk, Poland
}

\begin{abstract}
Finding a suitable place for overnight roosting may be crucial for survival during winter. If the number of suitable roosting sites is limited, intra- and interspecific competition may occur. In a nest box group, two cases of tit deaths were recorded in a winter season. The tits had apparent beak marks from pecks on their heads, and so were probably killed by other birds roosting in the boxes. Both dead individuals (a Blue Tit and young female of Great Tit) were competitively weaker individuals considering the hierarchy among wintering tits. They did not belong to the local winter flock. Presence of bird droppings on the bodies of the killed tits indicates that after the fight an individual (probably the winner of the competition) still roosted in the box. In both cases there was at least $57.7 \%$ of boxes that were not used by birds, suggesting that the birds fought for the best roosting sites. To the best of our knowledge, these are the first records concerning birds fighting for roosting sites during the winter season, which resulted in a death of one of the competing individuals.
\end{abstract}

Key words: Great Tit, Blue Tit, nest box, killing

\section{INTRODUCTION}

The availability of suitable tree cavities for hole-nesting birds can be limited, which has been studied mostly during the breeding season (Newton 1994). In that season competition between birds occurs mainly for a nesting site or for a potential partner, and in some cases may lead to severe injuries but rarely leads to death of a competitor. In Europe, interspecific fights between hole-nesters in competition for nesting sites are especially known for tits and flycatchers, where Great Tits Parus major (Linnaeus, 1758) kill Pied Flycatchers Ficedula hypoleuca (Pallas, 1764) or Collared Flycatchers Ficedula albicollis (Temminck, 1815) inside nest boxes (Merilä \& Wiggins 1995, Ahola et al. 2007). In North America similar observations concerned Eastern Bluebirds Sialia sialis (Linnaeus, 1758) killed by House Sparrows Passer domesticus (Linnaeus, 1758) (Gowaty 1984) or an exceptional case of the death of a pair of Tree Swallows Tachycineta bicolor (Vieillot, 1808) killed by an Eastern Bluebird (Frye \& Rogers 2004). Intra-specific fights resulting in deaths were described for the Starling Sturnus vulgaris (Linnaeus, 1758) (Flux \& Flux 1992) and in one case for the Tree Swallow (Lombardo 1986). Furthermore, a pair of birds from one species may take over a nesting site of the pair of another species (Busse \& Gotzman 1962); although the previous nest and eggs are usually destroyed by the aggressor, sometimes mixed clutches of both species may occur (Busse \& Gotzman 1962, Samplonius \& Both 2014).

Additionally, since a great number of hole-nesters use tree holes as a roosting site in the winter season, competition for these sites may also occur in this period (Newton 1998). Such competition has been demonstrated in experimental aviaries, where Great Tits displaced Blue Tits Cyanistes caeruleus (Linnaeus, 1758) from nest boxes (Kempenaers \& Dhondt 1991). Outside of the breeding season, inter- and intra-specific competition among birds concerns 
mostly a rivalry over food (Dingemanse \& Goede 2004) and roosting sites (Dhondt \& Eyckerman 1980, Kempenaers \& Dhondt 1991). The choice of a good quality roosting site significantly affects the energy savings during a long and cold winter night, which may decide a bird's survival (Pinowski et al. 2006, Velky et al. 2010). Thus, it is possible that deadly fights for roosting sites may occur between birds also in winter, as is known to occur for nesting sites in the breeding season. To the best of our knowledge, this kind of event has not yet been reported in scientific publications. Nor has it been unequivocally determined whether roosting in nest boxes increases or decreases the level of interspecific competition (Mainwaring 2011). Therefore, the current study documents for the first time inter- and intraspecific deadly fights for roosting sites in nest boxes during winter season.

\section{MATERIAL AND METHODS}

The reported cases of birds' deaths were detected during the long-term studies on ecology of wintering tits. At first observations were made on a small group of 26 nest boxes, situated over approximately one hectare at the area of the Ornithological Station, Museum and Institute of Zoology, Polish Academy of Sciences in Gdansk (OS MIZ PAS), N 54²0’58 E 1847’58. Nest boxes with dimensions of $13 \times 11 \times 26 \mathrm{~cm}$ (width, depth, height, respectively), and an entrance diameter of $34 \mathrm{~mm}$, were situated at a relatively high density, averaging every $13 \mathrm{~m}$, at a height of approximately $1.5 \mathrm{~m}$. The study area was similar in its characteristics to a deciduous forest with a well-developed undergrowth.

In the early autumn of 2010 old nests and bird droppings were removed from the boxes. The winter controls of nest boxes were performed during the daytime and they have taken place almost from the beginning of November 2010 to almost the end of April 2011, i.e. in a period in which birds are roosting in nest boxes and which precedes their breading season (Table 1). The number of inspections in each of 26 nest boxes was 16, that means a total of 416 checks. During a control, the presence and amount of droppings of roosting birds were recorded and then the bird droppings were removed from nest boxes. On the basis of the occurrence of droppings it was determined which nest boxes were occupied by roosting birds, according to assumptions made by Kania (1983) and later by Paclik and Tyller (2014). Capture of roosting birds in the whole nest box group was performed after dusk on 4 Jan 2011, once during the study, since capturing of the birds forces them to change their roosting site and can even deter them from roosting in nest boxes (Tyller et al. 2012).

Table 1. Dates of daytime inspections of nest boxes.

\begin{tabular}{ll}
\hline \multicolumn{1}{c}{ year-month } & \multicolumn{1}{c}{ day } \\
\hline 2010-Nov & 2,23 \\
2010-Dec & $2,14,22$ \\
2011-Jan & 4,15 \\
2011-Feb & 8,25 \\
2011-Mar & $7,11,17,28$ \\
2011-Apr & $5,11,20$ \\
\hline
\end{tabular}

Our further ecological research lasted for three more seasons: in winter of 2012/2013, 2013/2014 and 2014/2015 in a nest box group consisting of 50 nest boxes, located at the area of the Ornithological Station in Gdansk - in the same localisation as of the study revealing tits' fights to the death in competition for winter roosting sites. We checked, among others, whether a bird roosts consequently in the same nest box. We marked Great Tits and Blue Tits with plastic alphanumeric rings, which could be identified with the use of a video camera while entering of a bird to the nest box. The use of a camera enabled us to identify a bird without the need of catching it. We used video cameras with high optical zoom (25-35x), which were 
placed at dusk in a distance of about $3 \mathrm{~m}$ from the entrance to a nest box, in which droppings had been previously found. The recordings were irregular, since the video cameras were sensitive to weather conditions. Furthermore, a few times during each winter, birds were captured to identify their alphanumeric rings and to force them to change their roosting site. During these additional three winter seasons, the number of daytime inspections of 50 nest boxes was 28, which counts up to 1400 checks.

\section{RESULTS}

At the time of capture all of the birds (12 Great Tits and two Blue Tits) already possessed leg-rings, which had been fitted during trapping near the OS MIZ PAS bird feeder in the 2010/2011 winter season, or in previous years. The traces of nocturnal occupation of nest boxes were found in 7 to $17(26.92 \%-65.38 \%)$ of the nest boxes during each daytime inspection. A dead bird was found in the nest box twice - once it was a Great Tit and once a

Blue Tit. On both birds injuries were visible, which constituted evidences of fighting.

On 23 Nov 2010 a dead young female (in her first calendar year of life) (Svensson 1992) of Great Tit was found. The bird had numerous head injuries due to beak strokes, where at least four of them penetrated the skull. Furthermore, a few down feathers were left in the box, what can indicate that a fight had taken place inside. Fresh bird droppings were left on the dead tit, which indicates that after the fight another bird roosted in this nest box. In that time 15 of 26 boxes were likely to be freely available, as indicated by a lack of droppings or other traces. The last daytime inspection of nest boxes, preceding the finding of a dead tit, took place over two weeks earlier (Table 1). During the inspection, 24 fresh droppings had been found, which proves that the nest box was used at that time as a roosting site. On 4 Jan 2011 a young male of Great Tit (in his first calendar year of life) (Svensson 1992) was captured roosting in that box.

On 7 Mar 2011, in another nest box (130 m away from the first one), a dead young (in its second calendar year of life) (Svensson 1992) Blue Tit of an undetermined sex was discovered. One skull-penetrating wound was present on its head. In this case, fresh bird droppings were also found on the body of the dead tit, produced by a bird roosting in this box on several nights after the fight. Fifteen of 26 nest boxes were likely available to occupy in this period of time. The last daytime inspection of nest boxes, preceding the finding of the dead Blue Tit, also took place over two weeks earlier (Table 1). During the inspection, about 100 fresh droppings had been found, which proves that also that nest box was used then as a roosting site. In the same nest box, on 11 Apr 2011 an adult female of Great Tit was captured, although no nests were yet being built in any of the boxes in the group.

In contrast to other roosting birds, which had been captured in the nest boxes nearby OS MIZ PAS, both dead tits were not marked with rings, which suggested that they were immigrants or transients.

In the study testing whether an undisturbed tit is repeatedly roosting in the same nest box, during three winter seasons (2012/2013, 2013/2014, 2014/2015), we have obtained 25 video records of tits' entrances into nest boxes at dusk. The records concerned 19 different individuals (some of them have been recorded more than once). At that time 32 individuals were roosting in the studied nest box group. The time period between a recording of a bird's entrance to a nest box and its capturing was 3 to 73 days, median 34 days (standard deviation 21.15 days). Only in one case the individual registered by the camera as entering a given nesting box was not later captured in the same box. During the three winter seasons, no dead individuals have been found inside these 50 nest boxes. 


\section{DISCUSSION}

Roosting in concealment, e.g. in a hole or a nest box, permits the saving of up to $50 \%$ of energy in comparison to roosting in open spaces (Vel'ký et al. 2010). Therefore, a wellchosen roosting site can play a crucial role for survival during winter and, thus, could be a subject of inter- and intra-specific competition (Mainwaring 2011). However, fights that result in the death of one of the competing individuals are relatively rare among passerines (Lombardo 1986, Flux \& Flux 1992). The two presented cases demonstrate how severe this competition might be and the possibility that birds fight for roosting sites during winter similarly to fights during breeding season. The presence of deep head wounds on the killed individuals were recorded in both cases. Similar injuries were described on Pied Flycatchers and Collared Flycatchers killed by Great Tits during the breeding season (Merilä \& Wiggins 1995, Ahola et al. 2007).

Furthermore, the presence of droppings on the bodies of the killed tits is the evidence that the occupants of these nest boxes did not connect them with the threat from predators, which would probably steer them away from roosting in these sites, as it was stated by Ekner \& Tryjanowski (2008). Therefore, it supports the supposition that the dead birds were defeated and killed not by a predator, but during a fight with the occupants of these nest boxes. Tits are relatively consequent in their choice of a roosting site during winter and stay in the same roosting site on average for 34 days, as we have found in our study. This period was dependant on the time of performing the catching of the birds in nest boxes (for another part of the study). The studied birds changed their roosting site only after being disturbed, e.g. by a catching. Only one bird, which entrance to the nest box had been recorded on camera, was not caught in the same nest box afterwards. However, this observation concerned an individual, which had been recorded while only considering to enter the nest box, but it was startled (probably by a camera situated too close to the nest box) and did not enter the box at all. Therefore, in our opinion it is highly probable that the winner of the competition for a roosting site could have roosted for a long time in the obtained box and leave its droppings on the remains of the defeated individual. It would also suggests that tits' fights in competition for winter roosting sites can be intense and can lead to the death of the weaker of the competing individuals. Both dead birds were found in nest boxes that were later found to be occupied by a stronger (bigger) individual or one with a probable higher social status.

However, we can only speculate whether the killed female of a Great Tit (not possessing a leg-ring) had been previously occupying the nest box or it tried to take over a box already occupied by a young male of the same species .The hierarchy of a wintering flock of Great Tits is generally dominated by adult males, then young males, adult females and, eventually, the lowest place is reserved for young females (De Laet 1984, Dingemanse \& Goede 2004). Additionally, the lack of a ring on the dead Blue Tit suggests that it was a bird from the outside of the wintering flock, which tried to take possession of the box occupied by a female of a Great Tit.

A Great Tit is over 20\% larger and heavier than a Blue Tit (Cramp \& Perrins 1993), and both species compete for roosting sites during winter. In a study performed in an aviary it was revealed that Blue and Great Tits prefer nest boxes with the same entrance diameter. However, after Great Tits had been placed in the aviary Blue Tits, which are weaker, were forced to roost in boxes with a smaller entrance, too small for Great Tits to enter, or roost outside of nest boxes (Dhondt \& Eyckerman 1980, Kempenaers \& Dhondt 1991). The boxes used in the current study were accessible to both species. During the night-time capturing of birds the ratio of roosting Great Tits to Blue Tits was 6:1. During the same period of time 12 nest boxes were probably empty and accessible to roost in. This number varied depending on 
the date of inspection of the boxes; the most boxes were occupied $(\mathrm{N}=17)$ during the controls performed on 14 Dec 2010 and 4 Jan 2011, that is, not when dead birds were found. Thus, the probable reason for the above-described fights was not an insufficient number of free nest boxes, but rather their quality, e.g. potential parasite loads and thermal conditions, e.g. due to a different degree of exposure to sun (Christe et al. 1994, Merilä \& Allander 1995, Vel'ký et al. 2010). During winter season Great Tits prefer nest boxes with a better thermal insulation from the external environment and weather conditions (Vel'ký et al. 2010). This criterion might be very important in the described cases, since the 2010/11 winter season was unusually frosty in comparison to several previous winters. The first snow fell on 28 Nov 2010 and lasted until the end of February 2011 and temperature often dropped below $10^{\circ} \mathrm{C}$. Hence, weather conditions could have greatly increased the competition between birds, both inter- and intra-specific, and may have promoted aggressive behaviour meant to protect or overpower a good roosting site. During 2011 to 2015, at the same place, further research was conducted into the factors affecting the wintering of hole-nesters, and no additional deaths were observed in the nest boxes. There was, however, one observation of a fight between a Blue Tit and a Great Tit for a roosting site in a nest box. The Blue Tit lost the competition and flew away, whereas the Great Tit occupied the nest box afterwards.

The above observations suggest that competition for a winter roosting site in some cases may be very intense and lead to fighting, which can eventually result in the death of one of the competing individuals. This likelihood should be taken under consideration when performing studies of the wintering strategies of hole-nesters.

\section{ACKNOWLEDGEMENTS}

Presented data were gathered during long-term studies concerning winter ecology of tits, funded by an internal grant for young scientists, and a grant from the National Science Centre in Poland (DEC-2011/01/N/NZ8/03203), both awarded to Jakub A. Typiak.

\section{REFERENCES}

Ahola M. P., LAaksonen T., Eeva T. \& LehiKoinen E. 2007. Climate change can alter competitive relationships between resident and migratory birds. Journal of Animal Ecology. 76: 1045-1052.

BUSSE P. \& GOTZMAN J. 1962 Nesting competition and mixed clutches among some birds inhabiting the nest-boxes. Acta Ornithologica 7: 1-32.

Christe P., Oppliger A. \& RichneR H. 1994. Ectoparasite affects choice and use of roost sites in the great tit, Parus major. Animal Behaviour 47: 895-898.

Cramp S. \& PerRins C. M. 1993. The birds of the Western Palearctic. Vol. 7. Old World Flycatchers to Shrikes. Oxford University. Press, Oxford, 700 pp.

DE LAET J. 1984. Site-related dominance in the great tit Parus major. Ornis Scandinavica 15: 73-78.

DHONDT A. \& EYCKERMAN R. 1980. Competition between the Great Tit and Blue Tit outside the breeding season in field experiments. Ecology 61: 1291-1296.

Dingemanse N. J. \& DE GOEDE P. 2004. The relation between dominance and exploratory behavior is contextdependent in wild Great Tits. Behavioral Ecology 15: 1023-1030.

EKNER A. \& TRYJANOWSKI P. 2008. Do small hole nesting passerines detect cues left by a predator? A test on winter roosting sites. Acta Ornithologica. 43: 107-111.

FLUX J. E. C. \& FLUX M. M. 1992. Nature red in claw: how and why starlings kill each other. Notornis 39: 293-300.

FRYE G. G. \& Rogers K. K. 2004. Probable cavity usurpation via interspecific killing by the Mountain Bluebird (Sialia currucoides). Northwestern Naturalist 85: 126-128.

GowAty P. A. 1984. House Sparrows kill Eastern Bluebirds. Journal of Field Ornithology. 55: 378-380.

KANIA W. 1983. Diurnal investigations on roosting of birds in nest-boxes. Notatki Ornitologiczne 24: 69-72.

KempenAers B. \& DhondT A. A. 1991. Competition between Blue and Great Tit for roosting sites in winter: an aviary experiment. Ornis Scandinavica 22: 73-75.

LOMBARDO M. P. 1986. A possible case of adult intraspecific killing in the Tree Swallow. Condor 88: 112.

MAINWARING M. C. 2011. The use of nestboxes by roosting birds during the non-breeding season: a review of the costs and benefits. Ardea 99: 167-176. 
MERILÄ J. \& AlLANDER K. 1995. Do Great Tits (Parus major) prefer ectoparasite-free roost sites? An experiment. Ethology 99: 53-60.

MERILÄ J. \& WIGGINS D. 1995. Interspecific competition for nest holes causes adult mortality in the Collared Flycatcher. Condor 97: 445-450.

NEWTON I. 1994. The role of nest sites in limiting the numbers of hole-nesting birds: a review. Biological Conservation 70: 265-276.

NEWTON I. 1998. Population limitation in birds. Academic Press Limited. London, 598 pp.

PACLÍK M. \& TYlLER Z. 2014. Droppings as an indicator of nest box occupancy by roosting birds in winter. Sylvia 50:12-24.

Pinowski J., Haman A., Jerzak L., Pinowska B., Barkowska M., GrodZKi A. \& Haman K. 2006.The thermal properties of some nests of the Eurasian Tree Sparrow Passer montanus. Journal of Thermal Biology 31: 573-581.

SAmplonius J. M. \& BotH Ch. 2014 A Case of a Three Species Mixed Brood after Two Interspecific Nest Takeovers. Ardea 102(1): 105-107.

SVEnSSON L. 1992. Identification guide to European passerines. British Trust of Ornithology. Thetford, UK, 368 pp.

TYlLER Z., PACLIK M. \& ReMES V. 2012. Winter night inspections of nest boxes affect their occupancy and reuse for roosting by cavity nesting birds. Acta Ornithologica 47(1): 79-85.

VELKÝ M., KAŇUCH P. \& KRIŠTín A. 2010. Selection of winter roosts in the Great Tit Parus major: influence of microclimate. Journal of Ornithology 151: 147-153.

\section{STRESZCZENIE}

\section{[Dwa przypadki śmierci sikor $w$ wyniku walki o miejsca noclegowe $w$ sezonie zimowym]}

Znalezienie odpowiedniego miejsca do nocowania może stanowić o przeżyciu sezonu zimowego przez danego osobnika. W sytuacji niedoboru liczby miejsc noclegowych, może występować o nie między- lub wewnątrzgatunkowa konkurencja. Niniejszy manuskrypt zawiera opis dwóch przypadków śmierci sikor w wyniku walk o miejsce noclegowe w kolonii skrzynek lęgowych. Znalezione ptaki miały ślady uderzeń dzioba na głowie, przez co wnioskuje się, że zostały zabite przez inne ptaki nocujące w skrzynkach lęgowych. Oba martwe osobniki znajdowały się najniżej w hierarchii zimowego stada sikor (modraszka Cyanistes caeruleus (L.) i młoda samica bogatki Parus major (L.)) oraz nie należały do lokalnego zimującego stada. Obecność odchodów ptasich na ciałach zabitych sikor świadczy o nocowaniu w skrzynce lęgowej zwycięzcy już po odbyciu walki i to pomimo dużej dostępności $(57,7 \%)$ niezajętych skrzynek. Może to sugerować, że ptaki walczyły o preferowane miejsce. Zgodnie $\mathrm{z}$ naszą wiedzą jest to pierwsze doniesienie na temat walk ptaków o miejsce noclegowe $\mathrm{w}$ sezonie zimowym, które zakończyły się śmiercią jednego z konkurujących osobników. 